\title{
La Mayson pour Distiller des Eaües at El Escorial: Alchemy and Medicine at the Court of Philip II, $1556-1598$
}

\author{
MAR REY BUENO
}

\section{Introduction}

In 1593 the Irishman, Richard Stanyhurst, one of the most controversial figures of Elizabethan letters, wrote to his friend Sir Francis Englefield from the town of El Escorial near Madrid, commenting on his activities at the court of the elderly Philip II. The letter, dated 2 August, begins with various personal matters before moving on to a more detailed description of the work he had been called upon to do for the Spanish monarch.

Touching myne own affayres, I have not dealt as yet with his Majestie, nor with any of his officers, and doe purpose too use silence, until such tyme as I have accomplished such matters as are expected of me heere. A xv days his Majestie dyd apoynt too visit my wurches, but the physicians proceeding in theyr woonted malice, dyd diswayde his Majestie, saying the walk was too long from his chamber to the wurchhouse, and in the canicular days yt might be dangerous for hym to enter into those heates of the fyres and too smell too those strong waters, with sundry such bible babbles: too tedious too be written. ${ }^{1}$

Stanyhurst's words speak for themselves of the true nature of his activity at the court. It seems that the Irishman had been contracted by Philip II to work in an alchemist's laboratory installed in El Escorial complex, preparing all kinds of distilled waters and essences. The "prudent king" (el rey prudente), who was always portrayed by the black legend as an unbending counter-reformer intent on isolating his lands from any external influence that might threaten the purity of the Catholic faith, appears in the lines quoted above as being genuinely interested in the art of Hermes; challenging his personal physicians, visiting the laboratory where experiments, which were undoubtedly transmutational, were being carried out.

This information, published by Albert J Loomie in 1965, did not evoke the slightest interest among historians of science; it was common in the historiography of the modern age to ignore (almost totally) scientific practice in the Spain of the sixteenth and seventeenth centuries. Fortunately, this has changed in recent years, but it meant the exclusion from the international scene of what was, without a doubt, the first global empire and the most powerful monarchy of the period. ${ }^{2}$ The reign of Philip II is of special importance,

\footnotetext{
${ }^{1}$ The original letter is kept in the archive of St Alban's College in Valladolid (Spain) Series II, file 6. A copy can be seen in Albert J Loomie, 'Richard Stanyhurst in Spain: two unknown letters of August 1593', Huntington Library Quarterly, 1965, 28(2): 145-55, p. 152.

${ }^{2}$ Jorge Cañizares-Esguerra, 'Iberian science in the Renaissance: ignored how much longer?', Perspectives on Science, 2004, 12: 86-124.
} 


\section{La Mayson pour Distiller des Eaües at El Escorial}

given that he was profoundly interested in the sciences, and, thanks to his patronage, the court of Madrid became a meeting point for herbalists and doctors, astrologers and alchemists, natural philosophers and cosmographers. Immersed in the scientific culture of the Renaissance, Philip II established institutions for the advancement of knowledge, as well as financing expensive expeditions to discover the hidden natural treasures of his overseas possessions. $^{3}$

There was no area of natural philosophy that he did not follow, and alchemy, inevitably, formed an important part of his interests. It was considered to be one of the major sciences of early modern times, and its practice was promoted by patrons and the powerful, who saw it as a means of gaining wealth, prolonging life, and even acquiring a higher knowledge, suitable only for a few initiates. In this sense, Philip II can be seen as a forward-thinking monarch who promoted the development of new medicines elaborated by alchemical practices and the search for the Llullian essence. Both of these tasks were carried out in laboratories installed in the royal houses. In Aranjuez, Madrid, and El Escorial he established three impressive distillation laboratories with their respective gardens attached. Native and exotic flora, distilled waters and therapeutic essences; a perfect relationship for a monarch fascinated by the collection of diverse medicinal secrets. Because Philip II did not only collect Titians and Boschs in his palaces. A legion of gardeners, distillers, apothecaries and natural philosophers were employed to satisfy the demands of this avid collector. ${ }^{4}$

However, this massive undertaking was soon to be totally forgotten. The passing of the centuries has done the rest, and today little is known of Philip's passion. In this article, my intention is to present a synthesis of the work I have been doing in this area for the last fifteen years. ${ }^{5}$ I shall begin with the first news in the royal circle of alchemical practices connected with the transmutation of metals. These experiments have been interpreted as an attempt to find the gold necessary to cover the bankruptcies that characterized the whole of Philip's reign. I will continue with the presentation of Philip II as an avid collector of secrets; an aspect relatively unknown in the historiography, but one that is unsurprising, framed as it is by the artistic interests of the Hapsburg dynasty in particular, and the culture of the period in general. Finally I will make a special point of the passion that Philip II demonstrated for the world of distilled waters and essences; a passion which led him to

\footnotetext{
${ }^{3}$ There is ample evidence of this in various articles in Enrique Martínez Ruiz (ed.), Felipe II, la ciencia y la técnica, Madrid, Actas, 1999. In English, there is only the work of David Goodman, Power and penury: government, technology, and science in Philip II's Spain, Cambridge, Cambridge University Press, 1988.

${ }^{4}$ The subject of Philip II and alchemy has been treated in various studies (largely unnoticed) that have interpreted his interest from an esoteric and occultist perspective. In general they are full of errors, and make sweeping assessments on the basis of one or two facts, reflecting a lack of more detailed research in archives and libraries. This is the case of works like that of René Taylor, 'Architecture and magic: considerations on the idea of the Escorial', in Douglas Fraser, Howard Hibbard and Milton J Lewine (eds), Essays in the history of architecture, presented to Rudolf Wittkower, London, Phaidon, 1967, pp. 81-109; or more local articles, but ones that enjoy considerable prestige in Spanish historiography, such as Javier Ruiz, 'Los alquimistas de Felipe II', Historia 16, 1977, 12: 49-55; and F Javier Puerto Sarmiento, 'La panacea áurea. Alquimia y destilación en la corte de Felipe II (1527-1598)', Dynamis, 1997, 17: 107-40.

${ }^{5}$ My research in this area began with my doctoral thesis: Mar Rey Bueno, Los señores del fuego: destiladores $y$ espagíricos en la corte de los Austrias, Madrid, Corona Borealis, 2002. Since then I have been concentrating on the role of Philip II as a collector of secrets, and the influence that his interest in alchemy had on various members of the royal circle. See Mar Rey Bueno, 'El informe Valles: los desdibujados límites del arte de boticarios a finales del siglo XVI (1589-1594)', Asclepio, 2004, 56(2): 243-68; idem, 'Juntas de herbolarios y tertulias espagíricas: el círculo cortesano de Diego de Cortavila (1597-1657)’, Dynamis, 2004, 24: 243-67.
} 


\section{Mar Rey Bueno}

build a number of distillation laboratories, before undertaking the grandest of all, situated in the building that characterized his reign-El Escorial. ${ }^{6}$

\section{The Lords of Fire:}

\section{Unfulfilled Promises of Alchemical Gold}

In the summer of 1557, the young, recently crowned, Philip II controlled the largest empire known to the modern world. In addition to his possessions in Spain, England, the Low Countries with the Franche-Comté, and half of Italy, there were the fabulous lands of the New World and the Philippines. He had spent thirteen years preparing to assume the reins of government; sufficient time to have become the most travelled European leader, to have accumulated experience of international relations and met the illustrious personages of his time. For him, Augsburg, Milan, London, Cologne and Antwerp were not distant places, but cities whose streets he knew well.

Travelling from England, where he had left his wife Queen Mary, Philip II arrived in Brussels. There he was awaited by numerous young noblemen anxious to go to war with the enemy France. They did not have long to wait. Without warning, the French launched an attack on the border towns of the Low Countries. On Tuesday 10 August, the festival of Saint Lawrence, in a brief but bloody battle, the imperial armies defeated the French. It was a triumph brought about by God, according to Ruy Gómez, counsellor and confidant of the king, since it had been achieved despite a lack of soldiers, money and experience.

The ensuing months proved that the victory had been a pyrrhic one, as the troops were not prepared for the hard winter campaign, and the Flemish States General refused to provide more money. In a letter written to one of his senior officers, the Duke of Savoy, Philip said that he felt "strange not being able to provide the money to send off this army, since I do not have it. You will see that there is nothing for it but to deal with the Fúcar", 7 a reference to the Fugger family of bankers who had enriched themselves lending money to the emperor Charles. It was impossible to pay the expenses of the wars in the Low Countries and Italy. In letter after letter, a crushed and overwhelmed Philip pleaded with his sister Juana, then Regent in Spain, to send him more money; insisting that if his most immediate needs were not met, he would never achieve a peace. "We lack such a great sum that it's impossible to say. The task I have before me is bigger than you can imagine." 8

At the same time as these events, in Malines (Flanders), certain transmutation experiments were being carried out, the first we know of within the royal circle. An Italian alchemist, Tiberio della Rocea, an acquaintance of the Venetian ambassadors, was working

\footnotetext{
${ }^{6}$ When I was asked to write up this work, the editors specified that it should be a summary of the alchemical work of Philip II. I considered two options: one which looked at the bibliography published to date, and the other, which set out to present chronologically the diverse documentation of alchemical activity in the royal circle. Given that this is the first overview published in English, I judged it more appropriate to follow the second option.

7 “. . . cosa extraña no poder enviaros el dinero para despedir este ejército, mas pues no le tengo. Bien veis que no se puede hacer otra cosa sino tratar con el Fúcar". Letter from Brussels dated 8 Nov. 1557, British Library, London, Add. MSS 28264, fol. 37.

8 “... falta tan gran suma que no se puede decir. El trabajo en que estoy es mayor que podéis pensar." Archivo General de Simancas (AGS), Valladolid, Consejo de Juntas de Hacienda, file 34, fol. 519.
} 


\section{La Mayson pour Distiller des Eaües at El Escorial}

for the king in a specially installed laboratory. The operation failed, due to a disagreement with the royal confessor, Father Bernardo de Fresneda, who had been delegated to oversee the work. ${ }^{9}$ The same ambassador reported that, after the failure of the Italian alchemist, they had contracted the services of a German resident in Malines, who had mixed an ounce of one of his own powders with six of quicksilver, and had produced six ounces of silver that resisted "the hammer blow, but not the fire" (al tocco ed al martello, ma non al fuoco). According to the ambassador, they were considering paying the troops with this alchemical silver, although the king's advisers rejected the idea, fearing massive desertions of soldiers who were, after all, mercenaries. However, the report concludes,

But given that the invention has pleased the king and Ruy Gómez, and that he who undertook it has been generously rewarded, we may believe that in straitened times His Majesty may resort to it without further consideration. ${ }^{10}$

The German Peter Stenberg was another of the initiates in search of gold for the royal coffers working at the court at Malines. Although it was a highly secret activity, the Venetian ambassador, Marcantonio da Mula, managed to conduct an interview with the alchemist, who had no hesitation in discussing the nature of his work. ${ }^{11}$ Stenberg's experiments are confirmed by a second, more reliable source-the person charged with overseeing the work, Francisco Calderón, secretary to Antonio Pérez, the king's Chief Secretary. Two letters sent from Malines by Calderón to the monarch give a detailed account of the alchemist's activities. In the first, dated 8 March 1560, Calderón refers to another letter written two months earlier, where he described how he found the work in progress.

The material has turned black; in fifteen days, says the master, it will be more, and the putrefaction of the gold will be complete (as the alchemists say) ut deinde fiat generatio. Then after being very black, the material has to turn brown, then, little by little, white as snow and then red, and the work will be finished. God willing ... the satisfied alchemist assures me of it with examples and reasons that he has written down ... 12

This first letter concludes with an estimate of the duration of the experiment, seven or eight months.

The second letter begins by confirming that the work will be finished by the end of September, although the Maestro Pedro states that "it only involves the gold taking up all the humidity and water that was removed from it after converting it into salt, and this

\footnotetext{
9 “... ma non fu continuata, essendo occorsi certi dispareri fra lui ed il confessore del re, per e mani del quale passò tutta questa pratica". Michele Soriano, 'Relazione', in Eugenio Alberi (ed.), Relazioni degli ambasciatori veneti al Senato durante il secolo decimosesto, Florence, Società editrice fiorentina, 1839-1863, 15 vols, series 1, vol. 3 (Relazione di Spagna), 1853, p. 367.

10 "Ma perchè questa invenzione è molto grata al re ed a Ruy Gómez, e venne premiato largamente quello che l'ha ritrovata, si può credere che in tempo di qualche strettezza S. M. se ne valeria senza rispetto." (Ibid.)

${ }_{11}^{11}$ Marcantonio da Mula, 'Relazione', in Alberi (ed.), op. cit., note 9 above, p. 397.

12 "La materia toda se ha buelto negra, de aquí a quinze días dize el maestro lo estará más, y será acabada la putrefacción del oro (como los alquimistas dizen) ut deinde fiat generatio. En fin, después de muy negra, la materia se ha de volver parda y poco a poco blanca como nieve y después roxa, y será la obra acabada. Dios quiera que assí sea, el philósopho harto me lo certifica con exemplos y razones que para ello tiene escriptas." Letter of 8 March 1560 from Francisco Calderón to Philip II, AGS, Secretaría de Estado, file 521, no. 79.
} 
cannot be done without long delays". Calderón also reports a second experiment from which they would be able to extract "all the millions that the monarch might want". Three laboratory workers are labouring at it day and night. ${ }^{13}$ But then we hear nothing more of it.

All this information has been interpreted as an attempt by Philip II to acquire the gold necessary to finance his military adventures. ${ }^{14}$ However, we have in fact no evidence of his true intentions, but only the personal opinions of two Venetian ambassadors and a royal secretary. In general, recent historiography has maintained a double motive for Philip's interest in alchemy: material, during the first half of his reign, when he was searching for gold to pay his armies; and therapeutic, in the second half, when he sought a universal remedy that would extend his life, as he waited for the heir that would succeed him. Although I, too, have always firmly maintained this separation of motive, I now no longer believe that it is absolutely correct. Looking at the documents from a longer perspective, it seems evident that Philip II was very clear and consistent, right from the beginning of his reign, about his programme of distillation. We shall see this in the following pages. On the other hand, the various alchemists that he contracted to carry out the transmutation of metals were completely disparate, operating in different cities of the empire, supervised by men close to the king, but constituting only isolated episodes. All this points to a policy of employing the best craftsmen in the service of the crown, but without ever seeing the exercise of transmutation of metals as a solution to its economic problems. In fact we hear nothing more of the alchemists who had been employed in the Low Countries once Philip had returned to Spain. But it is then that the references to alchemical activities increase, and include all the different aspects of the Hermetic Art cultivated in the modern age.

\section{The Plant-Loving King: Physic Gardens and Distillation Laboratories}

In spring 1561 two years had passed since Philip II's return to Spain and he was still looking for a permanent base for his growing court. Having rejected Valladolid and Toledo, he opted for the small town of Madrid, whose Mudejar palace would be repaired and modernized.

At the age of twenty Philip had undertaken his first European tour, the "happy journey" (felicíssimo viaje) which had taken him to Savona, Genoa, Milan, Mantua, Trent, Innsbruck, Munich, Augsburg, Ulm, Vaihingen, Heidelberg and Brussels; an itinerary planned by the emperor Charles V so that his heir would learn about the lands he was to govern. This long journey, both educational and for pleasure, imbued the young Philip

\footnotetext{
13 “... solamente se entiende en bolver a consimir el oro toda la humidad y agua que se sacó dél después de convertirlo en sal, y esto no se puede hazer syno con larga detención. Vuestra Majestad sabrá cómo ha un mes que Maese Pedro començó a trabajar en una multiplicatión de oro, y hale salido hasta agora tan bien que si halla la fixación della valdrá más que la obra principal”. Letter of 18 March 1560 from Francisco Calderón to Philip II, AGS, Secretaría de Estado, file 521, no. 79. Both letters, as well as the fragments of the Relazioni in the footnotes 9, 10 and 11, have been published by Vicente González Ramos, 'Cuatro documentos para el estudio de la alquimia en la corte de Felipe II', Azogue, 2000, no. 3 (http://www.revistaazogue.com).

${ }^{14}$ Goodman, op. cit., note 3 above, pp. 12-13.
} 


\section{La Mayson pour Distiller des Eaües at El Escorial}

with a culture very different from that which he had known in his native Spain, but one that was in certain ways familiar, since it was inherited from his father. ${ }^{15}$

After visiting the great palaces and gardens of Italy, southern Germany, England and the Low countries, Philip embarked on an ambitious building programme in the capital and various surrounding towns. El Pardo, Valsaín, El Escorial and Aranjuez were transformed in the image of the European houses that had so impressed the young monarch. And, as he had never enjoyed the city environment, he did all he could to combine country and palace life, by establishing large gardens around his houses. An army of Dutch and Italian specialists was imported to create an extraordinary network of gardens which abounded in fruit trees, exotic plants, imported flowers from Flanders, artificial ponds and bridges. The gardens of Aranjuez were especially important, lovingly planned in all their detail by the monarch himself. They were designed in the image of those he had so much admired at Mariemont, the Flemish country residence built for Mary of Hungary, sister of Charles V, Regent of the Low Countries for a quarter of a century, and one of the most important patronesses and collectors of the Renaissance. ${ }^{16}$ With the intention of producing a copy of these Flemish gardens, Philip appointed Rugel Patie, a former treasurer and servant of his aunt, as major-domo, and head guard of the royal country house. Patie was charged with the task of creating "fields in the Flemish manner" (prados a la manera de Flandes), planting the trees in the way that was customary there. ${ }^{17}$ During the following years professional gardeners from various countries were employed, and were led by Jacques Hollebecque, Mary's gardener in Mariemont. Aranjuez was converted into a gigantic Eden. It included the "Island Garden", so called because it was set on an artificial island, surrounded by the Tagus river on three sides, and a canal on the southern side. This was where Philip chose to establish his garden of medicinal plants and a distillation house, dedicated to producing "distilled waters" from the plant simples cultivated there. He thus reproduced the design of the Mariemont gardens: one was called the jardin a jolietez, with parterres of exotic fruits and flowers, where he established the distillery (ung fourneau pour distiler les euawes) from which he obtained the essential oils of the garden's flowers. ${ }^{18}$

The person in charge of this garden, and expert distiller, was the Flemish Frank Hollebecque, brother of the head gardener. He was officially appointed Master Planter and Distiller by royal decree in September $1564 .{ }^{19}$ Among his duties was the manufacture of distilled waters and essential oils, and his normal residence was in Aranjuez. He was also required to travel to wherever the monarch needed his services, particularly to El Escorial, Segovia, Aceca and Toledo, the country houses most frequently used by Philip II. Reading

\footnotetext{
${ }^{15}$ This journey was recounted in detail by Juan Cristóbal Calvete de Estrella, El felicíssimo viaje del muy alto y muy poderoso Príncipe Don Phelippe, hijo del Emperador Don Carlos Quinto Máximo, desde España a sus tierras de la baxa Alemania, con la descripción de todos los Estados de Brabante y Flandes, Antwerp, Martín Nucio, 1552.

${ }^{16}$ Annemarie Jordan, 'Mujeres mecenas de la Casa de Austria y la infanta Isabel Clara Eugenia', in Alejandro Vergara (comp.), El arte en la corte de los Archiduques Alberto de Austria e Isabel Clara Eugenia (1598-1633): un reino imaginado, Madrid, Sociedad Estatal para la Conmemoración de los Centenarios de Felipe II y Carlos V, 1999, pp. 118-37.

${ }_{11}$ Archivo General del Palacio Real (AGP), Madrid, Cédulas Reales (CR) vol. II, fols 88v-91r.

${ }^{18}$ Krista De Jonge, 'Les jardins de Jacques Du Broeucq et Jacques Hollebecque à Binche, Mariemont et Boussu', in Carmen Añón Feliú (ed.), Felipe II, el rey íntimo: jardín y naturaleza en el siglo XVI, Madrid, Sociedad Estatal para la Conmemoración de los Centenarios de Felipe II y Carlos V, 1998, pp. 191-220.

${ }^{19}$ AGP, Madrid, CR, vol. II, fol. 448v.
} 


\section{Mar Rey Bueno}

the official documents, we see that the royal distiller was just another official in the service of the king, but fulfilled a special function in the health service of the court. Administratively, he depended on the Governor of Aranjuez, while in health matters he was responsible to the physicians of the royal chamber, who periodically required distilled waters for the royal pharmacy.

The distillation house of Aranjuez specialized in distilled waters from plant material: rosewater, wormwood, oxlip, fennel, chicory, marjoram and salsify were among the favourites of the royal family. Regular deliveries served the requirements of the court, and, in addition, various monasteries and convents also occasionally received provisions. For example, by 1573, approximately 300 litres a year were being sent out from Aranjuez. ${ }^{20}$ Its laboratory was the first step in a project to provide all the royal houses with attractive gardens whose plants could be used to distil essences. The distillers employed by the monarch were experts in these arts, very typical of the age; they took a practice that was basically alchemical and adapted it to therapeutic purposes. Thus these essences provided a useful addition to the Galenic medicine which had been used until then.

\section{The Collector of Secrets: Miracle Oils and the Clandestine Laboratory of the Court}

On 30 January 1567 the royal secretary, Pedro de Hoyo, wrote informing Philip that the furnaces had been built, and that all was ready to start the alchemical experiments. This is the first of fourteen confidential letters, exchanged by the king and his secretary, referring to an experiment in a laboratory concealed in the official's house. An experienced alchemist was attempting to convert a mixture of lead, silver, copper, and nitre, into gold; a technique more proper to metallurgists. The task was carried out over the following two weeks, and great efforts were made to keep it under cover.

The work has been carried out so well, and so secretly, that no one suspects anything-quite an achievement! But the equipment is set up in such a way that should Your Majesty wish to see it, there will be no problem ... ${ }^{21}$

In 1927, the discoverer of these notes and missives, Francisco Rodríguez Marín, presented them to the public in a series of lectures at the Royal Academy of Jurisprudence and Legislation in Madrid. Since then they have been the chief source of information about the alchemical legend surrounding Philip II, largely because they constitute a detailed diary of a specific experiment. ${ }^{22}$ They also give us the first documented opinions of the king.

${ }^{20}$ AGS, Madrid, Casas y Sitios Reales (CSR), file 248, fol. 123.

21 "Hánse hecho todas las diligencias con tan buena industria y secreto, que no se ha sospechado nada, que no ha sido poco; pero, cierto, el aparejo del aposento es de manera que, si Vuestra Majestad quisiere verlo, podría siendo servido, sin que se entendiese ni ningún inconveniente". See note 22 below.

${ }^{22}$ Currently kept in the Archive Francisco Rodríguez Marín (Library of the Centro de Ciencias Humanas y Sociales [CCHS], CSIC, Madrid), these documents were published in Reivindicación histórica del siglo XVI. Curso de conferencias dadas en la Real Academia de Jurisprudencia y Legislación (marzo a mayo 1927), Madrid, Imprenta de Ginés Hernández y Galo Sáez, 1928. I have worked with a copy of the original letters, generously provided by José Rodríguez Guerrero, editor of the electronic journal Azogue (http://www.revistaazogue.com) dedicated to the critical history of alchemy. Rodríguez Guerrero is currently finishing a review of this subject, and in his characteristically meticulous way, he has been able to puzzle out the identity of the anonymous alchemist whose 


\section{La Mayson pour Distiller des Eaües at El Escorial}

The truth is that although I am a sceptic in these matters, I'm not so sceptical about this. However it is better to be, because if it does not work out, I will not feel it so much. But from what I have seen so far and from how it seems to you, as regards both the work and the people, I do not feel so sceptical as I might; but soon we will see the end; we are assured that it is better to cut it short, as you say. ${ }^{23}$

Reading all the letters, we see how the king's scepticism gradually starts to be overcome by his secretary's enthusiasm. De Hoyo is a direct witness of the experiments, and as the days pass, he is increasingly convinced that there will be a successful outcome, a certainty that he expresses thus: “. . . pray to God that it is so, just as I hope for, because if it is, it will be the best business that has occurred since the time of Adam."24

The last news we have of this experiment is dated 20 February when certain technical problems started to appear, which led the artisans to ask for more materials and for the king to comment:

You have done well to permit them to do what they deem to be best, though I am not convinced by these moves. But perhaps it is better not to give them cause to complain that it failed because they had no freedom to act as they wished, and that they had to do it in so little time. ${ }^{25}$

It is a declaration that clearly demonstrates the king's experience in this type of business. We have no further information, but we may assume that the experiment failed. However, the king cannot have been disappointed for too long, as scarcely three weeks later, he managed to acquire the recipe of the oil of Aparicio (aceite de Aparicio) one of the most well-known ointments in sixteenth-century Spain, named after its creator Aparicio de Zubia. It was extremely popular among doctors and surgeons, who used it in the treatment of all kinds of injuries; and its composition was revealed by Aparicio's widow to Diego de Burgos, apothecary to the king, on 12 March 1567 . Only a year before, urged by Philip, the apothecary Burgos had acquired the secret of another famous Spanish oil, oil of Olmedo (aceite de Olmedo). ${ }^{26}$

name is never mentioned in the fourteen letters preserved. The results of his research will be published shortly in José Rodríguez Guerrero, 'Francés Esparza en las cortes de España y Navarra: guerras de religión, espionaje político y alquimia', Azogue, no. 6.

23 "En verdad que aunque yo soy incrédulo de estas cosas, que de ésta no lo estoy tanto. Aunque no es malo serlo, porque si no saliese, no se sintiese tanto. Pero de lo que hasta ahora se ha visto y a vos os parece, así de la obra como de las personas, no estoy tan incrédulo como lo estuviera si esto fuera así; pero ya presto veremos el fin, con todos nos acabaremos de asegurar, y muy bueno es acortarlo, como decís." Letter of 4 Feb. 1567 from Philip II to Pedro de Hoyo, Archivo Rodríguez Marín, CCHS-CSIC, Madrid, Box 85/2.

24 “... plega a Dios que sea así, como yo lo deseo, que siéndolo, el mayor negocio es que desde Adán acá ha sucedido." Letter of 9 Feb. 1567 from Pedro de Hoyo to Philip II, Archivo Rodríguez Marín, CCHS-CSIC, Box 85/2. In spite of his secretary's enthusiasm, the king remains calm, demonstrating his caution in lines such as: "You [Pedro del Hoyo] have worked well, and so am expecting good results, although I, who have seen a little of this, and seen that then it doesn't produce great quantities, am still wary." ("Vos [Pedro del Hoyo] lo habéis trabajado bien, y así, espero todo buen suceso, aunque yo, como he visto algo de esto y no salir después en cantidad, todavía estoy sospechoso.")

25 "Muy bien ha sido consentirles que hagan lo que les pareciere, aunque a mí no me contentan estas mudanzas; pero tanto más conviene no darles causa a que digan que no se acertó por no se hacer lo que les pareció, y tanto más, pues se podrá hacer esto en estos pocos días." Letter of 10 Feb. 1567 from Philip II to Pedro de Hoyo, Archivo Rodríguez Marín, CCHS-CSIC, Box 85/2.

${ }^{26}$ Both the original prescriptions were published years later in the Chirurgía universal of Juan Fragoso, one of the texts most commonly used among Spanish surgeons of the day. Juan Fragoso, Cirugia universal, Madrid, Viuda de Alonso Martín, 7th impression, 1627, pp. 471-2. It was made up of flowers of hypericon (St John's wort), 


\section{Mar Rey Bueno}

Philip's fame as a collector of secrets spread rapidly throughout Europe. As would occur years later at the court of his nephew Rudolf II, the Spanish capital became the meeting place of all kinds of artisans, anxious to show off their skills and to be worthy of royal patronage. Some simply sent petitions proclaiming the excellence of their knowledge. One such was fray Juan del Pozo, who in 1578 sent a missive informing the king of the numerous secrets he could relate, many of which were medicinal. ${ }^{27}$ Others invented concoctions and sent their recipes to the king's apothecaries. One was that of the doctor Pugino, creator of what was called "Pugino's infusion" (cocimiento de Pugino), which was passed from hand to hand until Pedro Gutiérrez de Arévalo, an apothecary of Madrid, decided to publish it in $1634 .^{28}$ There were even those who gave up fame and position to follow the hard road to gain the favour of the king. The Bolognese Leonardo Fioravanti, one of the most well-known professors of secrets in Europe, with published works to his name, arrived in Madrid in 1576 intending to offer his services. However he clashed with Diego Santiago Olivares, royal protomédico (protophysician), a determined opponent of these new "therapists", whom he considered to be fairground charlatans. ${ }^{29}$

The case of Fioravanti poses another question about Philip's passion for alchemy. His nephew Rudolf II was a faithful follower of his uncle's interests, having been educated at his court. He later sought out the most distinguished alchemists, astrologers, necromancers and natural philosophers in a desire to surround himself with the most prestigious names. However, Philip II tended to employ more anonymous artisans, recommended by people close to him. Why? We do not know the specific reason, but we may venture a few

valerian, and "blessed thistle" (Cnicus benedictus L.?). Fragoso states that in 1595, a new prescription appeared for this same oil in Segovia which was said to be the authentic one. Philip II charged his new apothecary Antonio del Espinar with preparing it. According to Fragoso it was a prescription that took several days to prepare, and contained more components than those offered by Aparicio's widow. Whatever the case, once Espinar had made it up, the royal pharmacy of Philip II used nothing else.

${ }^{27}$ The title Lo que el padre fray Juan del Pozo ofrece hará en servicio de Su Majestad y lo que para cada cosa es necesario proveer heads a minutely detailed list of activities among which appears the preparation of potable gold, oil of sulphur simple or complex, artificial balsam, varnish to brighten colours, and essences of orange blossom and myrtle flower. As well as these, he claims to know the secret of how to breed a large quantity of eels in a tank, how to cultivate oranges without having to cover them to protect them from the cold, and how to find a cave containing a variety of stones not seen for three centuries. The article was sent to the royal distiller Frank Hollebecque in charge of the laboratory at Aranjuez, who had no hesitation in supporting the proposals of the friar. However Philip rejected them, noting in the margin, "leave it, it looks to me like pure fantasy" (no hay que tratar porque lo tengo por cosa de aire). This petition is to be found, unedited, in AGS, Madrid, CSR, file 261, fol. 172. I am grateful to Miguel López who generously informed me of its existence, thus enabling it to be included in this study.

${ }^{28}$ Pedro Gutiérrez de Arévalo, Práctica de boticarios, guia de enfermeros, remedios para pobres, Madrid, María de Quiñones, 1634, pp. 100v-101v, where it states: "This recipe for infusion was invented and named by a Doctor of this Art, called the Doctor Pugino, and it was this recipe that was given to the pharmacy of his Majesty, that he did as he wished with it, and from whose original I made this transcription ... and as until now, nobody has printed it, but it is just written down in folders like a household recipe, many parts have come to be damaged, so I will take advantage of this occasion to serve the country, that its apothecaries might have the authentic version of Pugino's infusion." ("Este cocimiento lo inventó y puso su nombre un Médico desta Arte llamado el doctor Pugino, y esta receta fue la que dio a la Botica de Su Magestad, para que se hiziesse en ella, de cuyo original saqué este traslado ... y como hasta ahora nadie ha impreso este traslado, anda escrito en cartapacios como receta magistral, de donde viene a estar viciada en muchas partes, y pues la ocasión pide para tratar de cocimientos algo, en ninguno se puede tomar el assunto más bien que en éste, y haré de camino servicio a la República, en que tengan los Boticarios la receta verdadera del cozimiento de Pugino, tan general su uso en esta Corte como en otras partes.")

${ }^{29}$ William Eamon, 'The charlatan's trial: an Italian surgeon in the court of king Philip II, 1576-1577', Cronos, 2005, 8: 3-30. 


\section{La Mayson pour Distiller des Eaües at El Escorial}

possibilities. As a rule, the fact that this aspect of the king was surrounded with secrecy has been interpreted as a way of maintaining his public image as the prudent king, and his identification with the Counter-Reformation. However, the documented evidence suggests something much simpler. The king regarded his artisans as a means to an end, for the achievement of a desired result. Thus he did not so much seek out the most famous, as the most efficient.

\section{The Llullian Essence:}

\section{Neapolitan Distillers and American Plant Simples in the Royal House}

In 1570, Francisco Hernández, bound for the New World with the title of protomédico of the Indies, was charged by Philip II with the task of preparing a description of all the medicinal plants to be found in the American colonies. For seven years he travelled the length and breadth of New Spain, interviewing doctors, surgeons, herbalists, the native Indians, and anyone who might provide him with additional information. On the basis of this research, he prepared some forty-eight manuscript volumes to be printed in Spain to a standard that such a huge work merited. However, it was never published, largely because Hernández's personal interests got in the way. He wanted to go down in history as the new Pliny, but he committed the sin of not following the exact instructions of the king, who had required a mere description of the virtues and properties of the plants of the New World. His tactlessness condemned him to ostracism, once back in Madrid, and he was obliged to stand aside and watch as his material was passed on to a Neapolitan doctor, Nardo Antonio Recchi, to extract the relevant information, leaving the rest aside. ${ }^{30}$ Just two years later, Recchi finished the manuscript, which was presented to the king as "On medical matters in New Spain" (De materia medica Novae Hispaniae). ${ }^{31}$

This was not the only work undertaken by Recchi at the court of Philip II. According to a royal decree of 21 February 1580, he entered the service of the crown as a herbalist responsible for the planting and cultivation of herbs for medicinal purposes, and teaching the royal doctors the basics of distillation. ${ }^{32}$ Philip's concern to have his physicians taught was perhaps motivated by the fact that a new distillery had been built in the palace at Madrid. The land there, known as the Jardin de la Priora, had been prepared for the cultivation of medicinal plants; and the house called the "garden house" (casa del jardin) which had belonged to the royal apothecary, Diego de Burgos, was bought by the king in 1566, and became the residence of the new distiller and site of his laboratory. The new head of the distillery was the Neapolitan Giovanni Vincenzo Forte, whose task was to "distil waters and oils and to carry out those works related to his profession, necessary to provision

\footnotetext{
${ }^{30}$ For more information about the expedition of Francisco Hernández, see José María López Piñero and José Pardo Tomás, Nuevos materiales y noticias sobre la Historia de las plantas de Nueva España de Francisco Hernández, Valencia, Instituto de Historia de la Ciencia y Documentación, 1994; Simon Varey, Rafael Chabrán and Dora B Weiner (eds), Searching for the secrets of nature: the life and works of Dr. Francisco Hernández, Stanford, Stanford University Press, 2000.

${ }^{31}$ Raquel Álvarez Peláez and Francisco Fernández González, De materia medica Novae Hispaniae libri quatuor: cuatro libros sobre materia médica de Nueva España, Aranjuez, Doce Calles, 1998, 2 vols.

${ }^{32}$ Pascual Iborra, Historia del Protomedicato en España. Edición, introducción e índice de Juan Riera y Juan Granda-Juesas, Valladolid, Universidad de Valladolid, 1987, pp. 215-16.
} 


\section{Mar Rey Bueno}

our pharmacy". ${ }^{33}$ Forte's first days in Madrid were not easy ones. Whereas Hollebecque had never encountered problems in carrying out his work, right from the beginning Forte faced the opposition of the royal physicians, who saw him as a fraud, intent on enriching himself at the expense of the king. Especially negative was the opinion of the protomédico Olivares, who considered him as just one more charlatan among the many who had entered the court with the sole purpose of self-enrichment. However, Forte's task was clear from the beginning, as he himself set out in a letter to the king, "your Majesty ordered me many times to make a herbal essence, according to the instructions of Ramon Llull, for the health of human bodies, just as I had proposed to your Majesty". ${ }^{34}$ That is to say, what Philip seems to have wanted of his new distiller was the fabrication of the mythical Llullian essence, a common practice in alchemical circles of the late Middle Ages and Renaissance, a universal remedy produced by distillation, and sought by legions of distillers throughout the modern age. ${ }^{35}$ Thus the king's interest in alchemy was gradually moving towards its therapeutic uses, and away from the search for the mythical alchemical gold from transmutation by alchemists whose promises turned out to be nothing but smoke.

\section{The House of the Waters: Chemical Medicine and Potable Gold}

In early spring 1573 , Philip II handed 4,000 reales to his personal apothecary, Rafael de Arigón, with instructions to travel to Medina del Campo (Valladolid) in order to acquire all the plant simples necessary to set up a new pharmacy. ${ }^{36}$ What were these simples destined for? The royal decree is clear. They were to be used in the pharmacy of the monastery of San Lorenzo, in the town of El Escorial, the emblematic building of Philip's reign, built to commemorate the victory over the French at St Quentin. ${ }^{37}$ In the last decades of the sixteenth century, El Escorial became a great centre of learning. The original manuscripts of Hernández's expedition to New Spain were deposited there, and the most representative works of human knowledge were collected in its magnificent library. But the most prestigious of all its centres of activity were the distillation laboratories situated near the

\footnotetext{
33 “... destilar aguas y aceites y hacer las demás cosas y concernientes a su oficio que se le mandasen para provisión de nuestra botica". AGP, Madrid, CR, vol. V, fols 256v, 260r-v.

34 “... habbia V. M. comandato piu volte che me accomodino per fare una quinta essentia simple, secondo l'ordine de Raymundo Lulio, per la salute de corpi humani, la qual havea io proposto a V. M. ...". Letter from Giovanni Vincenzo Forte to Philip II, Instituto Valencia de Don Juan, Madrid, envío n . 99, fols 302-303.

${ }^{35}$ William Eamon, 'Pharmaceutical self-fashioning, or how to get rich and famous in the Renaissance medical fashion industry', Pharmacy in History, 2003, 45: 123-9.

${ }^{36}$ AGP, Madrid, CR, vol. IV, fols 20-20v. Arigón belonged to a family of apothecaries established in Valladolid in the first part of the sixteenth century. The earliest mention of their connection with Philip II dates from 1539 when the emperor Charles V established the first house of his son and heir, the Prince Philip, and chose Jean Jacques d'Arigón (whose name later was hispanicized to Juan de Arigón) as his personal apothecary. After the establishment of the court in Madrid, he, along with his brothers José and Rafael, were charged with dispensing medicines to the various royal houses.

${ }^{37}$ Philip II's intentions in planning El Escorial were, among others, to build a church dedicated to God, a palace for his own leisure, a monastery for the Order of Hieronymites, and a temple of the sciences.
} 


\section{La Mayson pour Distiller des Eaües at El Escorial}

monastic pharmacy, a real centre of investigation dedicated to a huge production of distilled waters and medicinal essences. ${ }^{38}$

The construction of the laboratory at El Escorial began in 1585, and was completed a year later. It consisted, according to the preserved documents, of a building around a rectangular courtyard, attached to the pharmacy, but independent of it and the monastery. There were two floors and a basement, the ground floor being divided into five rooms: two for distillation, one for presses and mortars, another for furnaces, and the last for essences. The upper floor consisted of two large spaces: one with a big furnace, and the other with the celebrated distillery of Mattioli, the distillation tower (torre filosofal) which became the emblem of Philip's programme. ${ }^{39}$ The building works and the design of the different distilling apparatuses were supervised by Giovanni Vincenzo Forte and fray Francisco de Bonilla, who was the apothecary of the monastery. The latter was put in charge of all the work carried out in the laboratory, which, although independent, came under the authority of the monastic pharmacy.

Between October 1587 and November 1589, they made all the stills, furnaces and baths necessary for the laboratory, which consisted of four distilleries. The first, on the ground floor, was made up of thirty-two distilling glasses set in a square box, which acted as a recipient for water vapour as a source of heat, brought from a boiler set apart from the box. The second, on the first floor, was the tower, twenty feet high, its perimeter the measurement of three men standing with their arms extended. It was an enormous contraption, designed to distil large volumes of water, between 180 and 200 pounds in twenty-four hours. It was the famous torre de Matiolo (Mattioli's tower) and took its name from the distillation towers described by Pietro Andrea Mattioli in his De ratione distillandi aquas ex omnibus plantis, an appendix to the Commentarii, in libros sex Pedacii Dioscoridis Anazarbei, De medica materia (Venice, 1554). It was formed of a hollow column of tin plates joined together, and reinforced on the inside by six iron bars. Its heat source was water vapour generated in a boiler near the base of the tower. In the same room as the tower, next to the wall, was the third distillery, an apparatus made up of twenty-six glasses, interconnected at different heights, placed over a copper boiler. Its purpose was to distil oils, and it was designed by Diego de Santiago, chief artisan of the laboratory at El Escorial, and author of the only Spanish work of the sixteenth century dedicated to the art of

\footnotetext{
${ }^{38}$ From the very beginning of the construction of the monastery, the religious community there and the officers of the crown had access to a pharmaceutical service in the town of El Escorial, organized at the orders of the king, and run by two brothers, Juan and Miguel Álvarez. The situation changed in 1573, when the monastic pharmacy was inaugurated. It was situated on the ground floor of the so-called Tower of the Infirmary. It was described by contemporaries as being large, very beautiful and clean. It was divided into three main areas: a large storage space for keeping the medicines, a rebotica (the apothecary's preparation room) and then six rooms in the basement where syrups, infusions and juices were prepared, as well as provision for storage of tools. See Rey Bueno, Los señores del fuego, op. cit., note 5 above, pp. 59-66.

${ }^{39}$ Our best description of the laboratory comes from the Murcian doctor Juan Alonso de Almela in 1594 in his Descripción de la octava maravilla del mundo que es la excelente y santa casa de San Lorenzo, el Real, monasterio de frailes Jerónimos y colegio de los mismos y seminario de letras humanas, y sepultura de reyes y casa de recogimiento y descanso después de los trabajos de gobierno. This manuscript is conserved in the Biblioteca Nacional, Madrid, MS. 1724. It was discovered by Gregorio de Andrés and published in the series Documentos para la historia del Monasterio de San Lorenzo el Real de El Escorial, Madrid, Imprenta Sáez, 1962, vol. 6, pp. 7-98.
} 


\section{Mar Rey Bueno}

distilling. ${ }^{40}$ The fourth distillery was also his. It consisted of three wooden boxes lined with brass or copper, set at right angles with the apex in the same boiler.

The laboratory at El Escorial specialized in the production of essential oils, essences, and the most sought after, mythical, potable gold. We have evidence of this activity from two contemporary witnesses. The first of these, the Flemish Jean l'Hermite, the king's valet, left a diary of his stay in Spain, in which he described the pharmacy at El Escorial, details of the distillations carried out and the plants used. ${ }^{41}$ In fact it was l'Hermite who first called the laboratory the Mayson pour distiller des eaües. The second witness was Juan del Castillo, a distiller of Cadiz, but of French origin, trained at El Escorial, who wrote a pharmacopoeia in which he stated that the main lesson he learned there was how to produce distilled oils, particularly those obtained from aromatic plants using the technique known as per descensum. ${ }^{42}$

Given the period in which it was established, and the importance of the work carried out there, the laboratory at El Escorial may be considered as Philip II's bequest to alchemy. His innate curiosity, natural in a monarch who was lord of so much of the known world, together with the illness that was slowly killing him and threatening the future of his monarchy, are reasons enough to explain the magnificence of the mayson des eaües at El Escorial. ${ }^{43}$ It was a meeting place for expert apothecaries such as fray Francisco de Bonilla,

\footnotetext{
${ }^{40}$ Diego de Santiago, Arte separatoria y modo de apartar todos los licores, que se sacan por vía de destilación, para que las medicinas obren con mayor virtud y presteza, Sevilla, Francisco Pérez, 1598. Among the most important works on the various personalities and their activities are: Sergio Caballero Villaldea, Diego de Santiago (alquimista, boticario y romancista del siglo XV). Su patria. Su profesión. Sus obras, Madrid, Imprenta Prensa Española, 1948; José Manuel Loring Palacios, 'Aportación de los destiladores de El Escorial a la fabricación de quintaesencias', in F Javier Campos and Fernández de Sevilla (eds), La ciencia en el Monasterio del Escorial, San Lorenzo, EDES, 1993, vol. 1, pp. 585-616; José María López Piñero and Eugenio Portela Marco, Arte separatoria de Diego de Santiago (Sevilla, 1598). Edición y estudio introductorio, Alicante, Fundación Gil Albert, 1994; Francisco Teixidó Gómez and Santiago Ferrera Escudero, 'Alquimia, química y filosofía alquímica en la obra del extremeño Diego de Santiago', Asclepio, 1998, 50(1): 31-47; Francisco Teixidó Gómez, 'Aspectos médicos del arte separatoria de Diego de Santiago', Asclepio, 1999, 51(1): 227-45; Rey Bueno, Los señores del fuego, op. cit., note 5 above, pp. 70-2; Miguel López Pérez, Asclepio renovado: alquimia y medicina en la España moderna (1500-1700), Madrid, Ediciones Corona Borealis, 2003, pp. 121-31.

${ }^{41}$ Jean l'Hermite, Les eaües qui s'y distillent sont de touttes sortes d'herbes, metaulx et especeries qui se peuvent penser, et en tyrent aussi les quint' essences dont les plus notables et curieuses qui s'y trouvent sont les suyvantes. Le memoire desquelles me donna un des distilateurs en la mese forme qu' il va icy mis. See Charles-Louis Ruelens, Émile Ouverleaux and Jules Jean Petit (eds), Le passetemps de Jehan Lhermite, depuis son voyage d'Espagne, 2 vols, Antwerp, J E Buschmann, 1890-1896. The original manuscript of L'Hermite's diary is held in the Royal Library Albert I, Brussels.

${ }^{42}$ Juan del Castillo, Pharmacopoea universa medicamenta in officinis pharmaceuticis usitata complectens et explicans, Cádiz, Ioannes de Borja, 1622. Castillo dedicates a large part of his Pharmacopeia to the preparation of oils (fols 251v-274v), a technique that he learned in the pharmacy at El Escorial, in particular the preparations for distillation: "I could describe many other forms of distillation, rarely used, if it was not for the fact that it is much better to watch the alchemist carrying out the operation, and seeing it, you will learn more quickly than by just hearing or reading about it. And as for essential oils, in the Pharmacy of St Hieronymus at El Escorial, and other places, seeing the process will produce better craftsmen." ("Otros muchos modos de distillaciones pudiera poner aquí, y por ser tan poco en uso, y fuera de que si no se ben distillar con mucha dificultad los harán, y es mejor que el curioso que quiziere saber lo bea hazer a un alquimista, y viendolo lo aprenderán más presto que por dicho ni escritos. Y para quintas essencias al Escurial en la Botica de S. Gerónimo, y otras partes que biéndolo saldrán buenos maestros." [fol. 257v.]) Castillo's comment indicates that the laboratory at El Escorial must have been an elite centre for distillations, as it was there more than anywhere else that he had acquired his skills; these were not simple techniques, but complex processes which required the explanations of master distillers.

${ }^{43}$ As the royal chronicler Luis Cabrera de Córdoba said, "It was so curious that, as his illnesses were ageing him, causing him to take simple and compound medicines, he ordered the construction of distilleries in San Lorenzo, of
} 


\section{La Mayson pour Distiller des Eaües at El Escorial}

the experienced distillers Giovanni Vincenzo Forte, Diego de Santiago, Antonio Kannegieter and Joost Fraye, and distinguished natural philosophers like Richard Stanyhurst. Sadly, there is little trace of the work they did there, which must have been considerable; only isolated and scattered evidence remains, which makes it difficult to visualize from such a distance the magnitude of the monastic laboratory. Although we may be surprised by the absence of written evidence from those involved, we must not forget that they were employed by the most powerful monarch in Christendom, who wanted their work to remain secret. Stanyhurst confirms this in the letters preserved in St Alban's College: his work at El Escorial was a matter of state, considered highly confidential, whose particulars should never be revealed to anyone outside the confines of the laboratory.

\section{Conclusion: \\ The Passion for Alchemy of the Rey Prudente}

Thus we see that Philip II maintained a close interest in alchemy throughout his life; it was a fascination that, despite certain claims, had nothing whatever to do with the world of the occult, but rather should be interpreted as normal for the times in which he lived. An avid collector, an important statesman, a broad-sighted European, it was natural for him to be interested in a science like alchemy which had such great possibilities, both material and spiritual. What for other contemporaries was entertainment, a form of relaxation from the arduous business of state, became for him a secret of state, a means to achieve the best possible results, and put them to the service of his empire. In this sense, his passionate enthusiasm for alchemy should, once and for all, be brought out from its dark corner in the historiography, and occupy the privileged position that it deserves.

such a huge capacity, of extreme and varied shapes, all to such a high standard, that only a prince with his curiosity and power could undertake. And he brought Vincencio Forte and other foreign craftsmen to distill quintessential oils; substances that are called subtle, intrinsical and simple radical humour, separated into their elemental parts, which keep their properties for a long period of time, ordered by Nature to preserve individual lives. Yet if our food is made from dead matter, and the material of gold and pearls is inanimate, I do not see what good effect they [the quintessential oils] would have. The craftsmen could develop and perfect their techniques, thanks to his support; they grew in number, thanks to his communication, and they flourished, provided they worked in such a way that accorded with his aims." ("Fue tan curioso, que envejeciéndole más las enfermedades, forzándole al uso de las medicinas simples y compuestas, mandó hacer en San Lorenzo distilatorios de capacidad grandísima y extremadas y varias figuras, con tal excelencia que solamente un príncipe tan curioso y poderoso las pudiera hacer, y truxo a Vincencio Forte y otros extranjeros artífices para sacar las quintas esencias, que llaman sustancia sutil y húmido radical intrínseco y simple, difundido en las partes elementadas, que largo tiempo mantiene las cosas en su ser, ordenada de la naturaleza para conservar individuos. Aunque si el alimento se hace de los muertos, y la materia del oro y perlas no vivió, no sé de qué efecto sea. Criáronse y habilitaron con su amparo, y perficionaron y florecieron los artífices en gran número con su comunicación, porque de poner una cosa de sí propios a como él la acomodaba, iba el parecer bien o mal.") Luis Cabrera de Córdoba, Felipe Segundo, Rey de España, 4 vols, Madrid, Sucesores de Rivadeneyra, 1876-1877, vol. 2, pp. 392-3. 